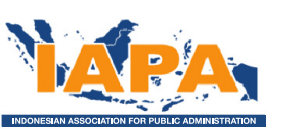

\title{
\begin{tabular}{r|l} 
POLICY\&GOVERNANCE & PGR \\
REVIEW & PG
\end{tabular}
}

\section{Severinus Mau}

Human Resources Development \& Personnel Agency, Belu Regency, East Nusa Tenggara Province

Email: jefriatb@gmail.com

\section{A.G. Subarsono}

Department of Public Policy and Management, Faculty of Social and Political Sciences, Universitas Gadjah Mada, Yogyakarta

Email: barsono@yahoo.com

\section{Yuyun Purbokusumo}

Department of Public Policy and Management, Faculty of Social and Political Sciences, Universitas Gadjah Mada, Yogyakarta

Email: yuyun@ugm.ac.id

Submitted: 18 August 2020, Revised: 22 September 2020, Accepted: 23 September 2020

\section{Severinus Mau}

Civil servants in Human Resources Development \& Personnel Agency

Belu Regency - East Nusa

Tenggara Province, was born in

Atambua, Indonesia, 21 November

1975. Graduate from the Faculty

of Business and Econmoics,

Universitas Atma Jaya Yogyakarta,

Indonesia, with specialization

on Management. Her master of

Communication Studies academic

degree is obtained from Universitas

Gadjah Mada Yogyakarta, with

specialization in Management of

Communication, and became the

best student on graduation October

2014. Since 2015 he has studied

doctoral program at the Department

of Public Policy and Management,

Faculty of Social and Political

Sciences, Universitas Gadjah Mada,

Indonesia.

\section{Agustinus Subarsono is lecturer in Department of Public Administration (PPM), Faculty of Social and Political Sciences, Universitas Gadjah Mada, Indonesia. He is currently as Director of Public Policy and Management Studies in MKP. He graduated Bachelor (S1) in 1983 form Universitas Gadjah Mada, Indonesia, then he obtained master in Development Studies from Flinders University, South Australia in 1996. He obtained Ph.D from Curtin University of Technology, Western Australia. His Ph.D Thesis on The Impact of Desentralization Policy on Small Business in Indonesia: A Study of \\ Policy \& Governance Review ISSN 2580-4820 \\ Vol. 4, Issue 3, pp. 245-261 \\ DOI: https://doi.org/10.30589/pgr. v4i3.356}

\section{The Merit System's Adaptation to the Implementation of Bureaucratic Official Recruitment and Promotion Policy in South Central Timor Regency}

\begin{abstract}
The inequality of human resource (HR) capacity among bureaucrats is an immense challenge confronted by the South Central Timor (SCT) regional government concerning the policy for recruiting and promoting bureaucratic positions. The strong ecological characteristics of the local community with its diverse and varying social, cultural, geographical, economic, and educational environments, coupled with salience of kinship and affiliation have set the backdrop for differences in the bureaucratic personnel's capacity and performance. Such conditions make it difficult for regional bureaucracies to avoid the emergence of HR capacity disparity issues among bureaucrats. The current study aims to identify and analyze the implementation of bureaucratic position promotion and recruitment policy in SCT Regency. The post-positivist approach was employed in the research by using the descriptive qualitative method. Data were collected through observations, literature study, document study, and in-depth interviews to obtain information, perspectives, and opinions from relevant sources. By comparing theoretical and empirical models, and using the construction of cultural and structural approach models, study results indicate that the merit system's adaptation developed in recruiting and promoting SCT Regency's bureaucratic officials tends to use rational representation. This means ethnic representation and native son priority are accommodated in the policy for recruiting and promoting SCT government officials as a manifestation of an achieved mutual consensus, although the process must be conducted through a professional system based on qualifications, competence, and institutional needs.
\end{abstract}

\section{Keywords:}

recruitment and promotion; competence; merit system adaptation; rational representation. 
Politics in Bantul Distric, Yogyakarta and Gianyar Distric, Bali. In undergraduate program he teaches theory of development and public policy, and in postgraduate program he teaches regional autonomy and policy formulation.

\section{Yuyun Purbokusumo}

is an Associate Professor at the Department of Public Policy and Management, Faculty of

Social and Political Sciences, Universitas Gadjah Mada, Indonesia. He received his Ph.D form the Department of Business Administration, National Central University, Taiwan and his Master in the Master Programme in Public Policy and Administration, Universitas Gadjah Mada, Indonesia. He has published several papers in Electronic Government: an International Journal, Enterprise Information System, and others. His research interests include e-government and disaster management.

\section{Introduction}

The merit system has been much discussed by scholars in the field of public administration, management, and other scientific disciplines (Weber, 1904/1958; McCloscky \& Zaller, 1984; Henry, 1995; Hale, 1995; Jost, Pelham, \& Carvallo, 2002; Jost \& Hunyady, 2005; Jost, Ledgerwood, \& Hardin, 2008). Lexically speaking, the merit system may be construed as a social system in which progress within an organization is established based on individual competence instead of kinship or other social backgrounds (Bellows, 2009; Castilla \& Benard, 2010; Poocharoen \& Brillantes, 2013; Imbroscio, 2016). The merit system may also be defined as a proportional justice mechanism for treating and awarding conducts considered admirable (Hormby, in Wungu, 2003).

Several thoughts and study results indicate that the merit system is considered as the most feasible mechanism for developing the bureaucracy's human resource (HR) capacity because it provides an illustration of professional and proportional bureaucratic management. In the merit system, each person is considered to have the exact same opportunity for achieving individual career advancement or gaining appreciation according to their respective contributions. Such conditions indicate that there is a distributive justice model in the merit-based HR development concept. HR with higher capacities and contributions have greater chances to achieve career development and performance appreciation compared to HR with lower ones.

McCourt (2007, p. 5) defines the merit system as "the appointment of the best person for any given job". Hence, a job or position should be held by the best people on account of their quality and competence (Herman, 2012, p. 67), instead of ascriptive factors such as social class, gender, ethnicity, or even wealth (Kumorotomo, 2006, p. 4).

Stahl, in Public Personnel Administration, discusses the meritocracy concept in the context of modern society, as having a more extensive meaning than job selection. Stahl argues that nowadays the term meritocracy is not only used to convey a form of entry selection in a service, but the term has also become more widely used in other aspects throughout the personnel system, such as remuneration, performance assessment, and desired working conditions. Broadly speaking, meritocracy in modern public administration is a personnel system wherein each individual is selected based on competence and performance in providing public services (Stahl, 1971, p. 30).

Gordon describes meritocracy by emphasizing work competence and rejecting patronage relating to loyalty and political connections. Meritocracy offers personnel continuity and stability while patronage allows executives to favor loyal subordinates. So, in practice both are 
overlapping (Gordon, 1982, p. 335). Additionally, according to Van Riper (1971), a country applying the concept of meritocracy is (1) able to distribute public service officers more rationally and systematically than a spoils system approach; and (2) able to prevent potential corruption and combination of business and political oligarchies that often thrive within a spoils system.

Meritocracy has provided equal opportunities for lower-level members of the society to raise their social status, economic class, and decent place in a hierarchy, and it has instilled the ideology that everyone has equal opportunity to succeed as long as they have the ability to cultivate the capacity required in society (Wiederkehr et al., 2015). In this context, meritocracy functions as a machine that maintains social order. The value of social equity is achieved when an organized and balanced society has been established wherein all citizens have the opportunity to build a decent life and fragile communities can receive assistance as necessary (Irawan, 2017).

Descriptions of the studies above are ideal conditions pertaining to meritocracy that emphasizes on the significance of employee selection and promotion based on competence instead of other irrelevant considerations. This implies that clear and universally acceptable standards should apply to all personnel in the organization when giving promotions to ensure maximum public administration performance (La Palombara, 1967; Warwick, 1975; Collins, 1986).

The general description of the studies above is that, essentially, public service becomes more rational and systematic if meritocracy is used in the selection process (recruitment, placement, promotion, and transfer). This approach's basic assumption is that the selection system in public bureaucracy should be able to recruit the best personnel, and meritocracy is the tool to achieve that end.

So, what if these ideas on meritocracy are contextualized in the geographical and demographical conditions of East and Southeast Asia, including Indonesia? Observations by Turner and Halligan (1999) (cfr. Handerson and Dwivedi, 1999) suggest that, in terms of geographical and demographical aspects, East and Southeast Asia, including Indonesia, are of great interest because the region has extremely diverse ethnicities, cultures, languages, and politics that are distinct from one another. These distinctions are prompted by the different features each country maintains, particularly in the government system applied for power acquisition, which is inseparable from ethnic and cultural values.

According to Turner and Haligan (1999), policies for recruiting, promoting, and appointing officials to fill government positions that is in line with the bureaucratic principles in East Asia and Southeast Asia are often similar to the recruitment model of bureaucratic organizations Weber developed. Similarly, according to Dwivedi, 2001 \& Cheung, 2013 (in Saputra et al., 2018), developing countries including Indonesia tend to imitate public administration practices of the Western model rather than explore existing indigenous practices (local wisdoms) inherited from past generations. Consequently, the Western model of public administration practices are commonly unsuitable with the conditions and challenges confronted by adopting nations.

Another example is the bureaucracy in Indonesia that exists within a social ecology different to that of the West. The meritocracy implementation case in Papua is an example. Meritocracy values, prioritizing competition, competence, and abandoning nepotism, frequently go against local values that accentuate clan solidarity as a merit. Assisting the clan's family members is a noble social obligation, yet it is highly contradictory to meritocracy practices developed in Western bureaucracy. Another example is found in Yogyakarta with its special administrative system based on a monarchical system. Within the power structure, the monarchical system 
is established upon the basis of traditional and charismatic legitimacy. Power and authority is centered on the monarch, not the regulation. This is antithetical to Weber's rational-legal authority model that places rule of law above power (Hoadley, 2006 in Saputra et al., 2018, p. 280-281).

Based on the above cases, it can be said that the various concepts developed in the Western model public administration has not been entirely accepted into the social culture of developing countries that tend to be multicultural; even the majority of people who still maintain strong ties with their local tradition view the Western model as a hindrance to public entity itself. According to Riggs (1979), the ecology determines the success or failure of public administration practices (Saputra et al., 2018, pp. 280-281).

Every country has its own political or administrative system, wherein we can find policies and standard procedures concerning recruitment or selection and promotion as well as placement of political or administrative officials to conduct state authority. In reality, recruited officials for both political and public administration offices are a public minority. The recruitment and promotion process for these elites are, thus, expected to indicate the effectiveness of work that government bureaucracy conducts. In relation to that, Mas'oed \& Mac Andrews (1991, p. 50) state that democratic countries, like the United States, England, and France, officially open political and administrative positions to any eligible candidates. They generally tend to be individuals with middle-class background, and lower-class people who succeeded in acquiring decent education. Normally, the recruitment and promotion process never questions primordialist matters like ethnic group, religion, language, etc. That is why only knowledge and competence are required in that process.

In contrast, the recruitment and promotion process for official political and administrative positions in developing countries, including
Indonesia, is often closed and not properly formulated. Although candidates for those positions come from educated lower, middle, and upper social classes (Rush \& Althoff, 2003). In relation to that study, Riggs (1996) elaborated an elite recruitment model often used in developed countries with diffracted communities by separating recruitment of elites outside of the bureaucracy, namely through political parties, and recruitment within the bureaucracy, which is the desire to gain a position in the government with the satisfaction of attaining a professional career level. For example, new employee recruitment based on a screening process disregarding kinship network. Meanwhile, in the prismatic model, mostly found in developing/transitioning countries or known as a fused society model, the recruitment of officials or employees, although based on test results (formalistic), still reflects nepotistic features, wherein assessor consideration is a substantial determinant in the non-ascriptive testing. This is due to the recruitment being focused on family interests and nepotism.

In developed societies (diffracted model), the challenges in job recruitment and promotion is based mainly on professionalism; but in developing (prismatic) societies, recruitment and promotion, aside from being based on professionalism, are also based on the expectation of gaining the title as a ruler. This means that in practice a director is not only chosen based on technical competence, but also on views concerning political mobility or ability to obtain proper status as a political elite or good bureaucratic career. The recruited elites are directed in relation with potential power/authority, position, or professional responsibility, and officials with the authority to recruit new employees or officials tend to be more interested in potential influences that reinforce their positions than administrative consequences. When confronted to choose between loyalty and work competence, the recruited officials or elites subsequently favor loyalty. Recruitment of family, close friends based on ethnicity is considered 
necessary for elites and officials to strengthen their position, namely by trusting the people they recruit.

In Indonesia, the merit-system-based HR development policy used in running the bureaucracy is regulated in Law No. 5/2014 on State Civil Apparatus (UU ASN). The challenge lies in the difference of paradigm between the central and regional governments concerning the merit system policy in the mechanism of bureaucratic position promotion and recruitment. The central government's paradigm emphasizes on meritsystem-based HR development in running the bureaucracy. Meanwhile, at the regional government level, the government tend to employ a paradigm that considers different cultural settings and contexts along with characteristics of cultural and value systems inherent in their communities, which include other factors such as the limitation and disparity of HR capacities among bureaucrats in the regions.

Given such conditions, a link between the central and local paradigms needs to be established so both paradigms can synergize reciprocally to provide public services aimed at developing and increasing public welfare within the framework of the unitary state of the Republic of Indonesia.

Accordingly, we conducted a deeper study on how the merit system adapts to practices of bureaucratic official recruitment and promotion in South Central Timor Regency (SCTR). The study is focused merely on the recruitment and promotion of first level senior executive service and office administrator (Structural Positions according to UU ASN No. 5/2014) or Echelon II and Echelon III.a positions (Structural Positions according to Law No. 43/1999).

\section{Literature Study}

\section{Recruitment of Bureaucratic Elites}

In the perspective of public organization, Bernadin \& Russel (1993, p. 201) state recruitment is the process of finding and drafting interested applicants meeting qualifications required by the vacancy. As McKenna and Beech (1996, p. 119) declared the recruitment concept is a process of drafting a group of candidates to fill in vacant positions. In a different perspective, recruitment may enable power rotation to occur. This means anyone meeting the conditions of filling in a position, be it a political position elected by the people or an administrative position.

Similarly, Czudnowski (1975, p. 172) states that recruitment is a link between the public and the political system, wherein the relationship contains the following three bases: First, every political order requires institutional continuity, but continuity also implies change of personnel; Second, government policy-making tends to emphasize relevance, consistency, and effectiveness. But, the public's cultural, social, and economic life tend to change constantly; Third, government is founded on authority, but to gain legitimacy the government must demonstrate public accountability.

Czudnowski also posits, recruitment may serve as a means for resolving dilemmas within a certain period of time. Consequently, recruitment functions to preserve the system and usher in major changes, by recruiting members of the society and involving them in certain roles.

Based on the above arguments, two main ideas can be asserted, namely: first, recruitment is a process capable of producing elites who can become leaders holding administrative, political, or government positions for exercising power and maintaining continuity of the state's political system; second, by carrying out the recruitment procedure based on the existing rules, recruitment may thus have an impact on elites, including the desired regional government officials, with the expectation that it can circumvent the public's aspirations or desire. Undoubtedly, the most significant points of considerations are education background, competence, expertise, talent, and high level of professionalism resulting in 
achievements instead of primordialism-based ascriptions.

Concerning the recruitment and promotion of bureaucratic officials, Geddes in Masdar (2008) proposes a typology of recruitment strategy used by the executive in choosing a "supporting system" in their administration. Geddes' reasoning can also be used to examine the concept of bureaucratic promotion that executives conduct in the regions. The following are the four types of recruitment strategy proposed by Geddes:

The first type is called civil service reform. In this typology, the consideration for recruiting top bureaucratic officials is the merit system, taking competence and loyalty into account.

The second type is known as compartmentalization, i.e. a bureaucratic recruitment strategy utilizing principles of political selection for top bureaucratic officials based on considerations of loyalty and competence. What distinguishes this with the first type is that in the bureaucratic strategic positions below them- particularly in institutions that the executive consider as highly important and strategic-selection is performed by employing informal merit system considerations. As for lower bureaucratic ranks, recruitment is commonly done through patronage channels controlled by the executive, political parties, or coalition partners.

The third type of recruitment uses a partisan strategy. In this recruitment typology, top level administrative positions are recruited based on considerations of political proximity and affiliations to rulers; competence values are less considered. Additionally, party cadres are also positioned in institutions considered strategic and crucial in determining the success of the ruler's programs. Another common phenomenon observed in this typology is the domination of street-level bureaucracy recruitment channels by the ruling party or its coalition partners.

The fourth type is called immediate survival. Recruitment of top bureaucratic officials disregards the competence of candidates for groups that have contributed to the incumbent. Appointments are also followed by the authority to recruit subordinates. Recruitment for other policymaking positions is based on considerations of resources that "applicants" have and the authority to recruit others. Recruitments for other posts are achieved through patronage controlled by supporters of the executive.

Almond \& Coleman (1996) suggests at least two recruitment models in a political system that are applicable as of current. The first model is the ascriptive style, wherein individuals are selected to hold a certain position based on bloodline and social status, gender, race, ethnicity, and religious affiliation. The second model is called achievement-oriented recruitment, which emphasizes more on technical expertise and leadership as necessary occupational elements and avoids collusion in every policy that will be made. By adopting Almond's argument, the study focuses on examining practices of bureaucratic official recruitment and promotion in SCTR.

\section{Representative Bureaucracy}

Kim (1996, pp. 228-229) summarizes various perspectives of scholars and political scientists such as Pitkin (1967), Dixon (1968), Birch (1969), Fishel (1973), Ealau \& Karps (1977), Weisberg (1978), Engstrom \& MacDonald (1981), Jennings \& Callahan (1985) who conducted studies on representative government with a focus on the legislative branch. Meanwhile, there are scholars with similar attention on the study of representative bureaucratic institutions such as Rosenbloom (1973), Nachmias (1973), Krislov (1974), Meier (1975), Meier \& Nigro (1976), Saltzstein (1979), Rehfuss (1986), Stein (1986), Lewis (1988).

Representative bureaucracy is considered to have contributed significantly in establishing an ideal democratic process in the public sector, wherein varying elements in society are represented in decision-making institutions, 
which accordingly administer and oversee the public's needs and interests. The bureaucracy shall represent all elements in the population and can provide anyone service in various significant opportunities.

Kernaghan (1991, p. 228) stated that representative bureaucracy is a micro cosmos or miniature of society as a whole. This perspective is frequently used to explain the relationship between development and public officials. Proponents of this argument, based on Kim's (1992) summary, are Lewis (1990), Gallas (1985), Goodsell (1983), Krislov (1974), Subramaniam (1967), Riper (1958), Long (1952), and Kingsley (1944).

Kernaghan (1991:235), thus, viewed representative bureaucracy as a miniature description of society as a whole that can become administrative responsibility reinforced by government officials' responsive attitude toward the public. Officials are believed to possess social backgrounds that influence the policies they formulated and implement, ultimately producing policies aspired by social groups in the populace, including local communities.

Correspondingly, Warner (2001) argues that representativeness in the bureaucracy develops greater balance and democratic zeal by allowing local community representatives access to power, implying that power/authority is exercised based on powers of regional representatives accommodating social groups within government bureaucracy. Such accommodation is expected so that the democratic process in pluralistic or multiethnic countries can be managed through the representativeness approach.

Based on the representative bureaucracy concept elaborated above, Kernaghan (1991) and Warner (2001) are employed as analytical scalpels to support the recruitment concept in examining the implementation of bureaucratic official recruitment and promotion in SCTR.

\section{Methods}

The post-positivist approach is employed in the research by using the qualitative descriptive method to provide analyses on how the merit system adapts to the policy on bureaucratic official recruitment and promotion in SCTR. Research data were collected using various techniques such as observation, literature study, document study, and in-depth interviews to gain information, perspectives, and opinions from relevant sources. Data analysis in the research was done using the NVIVO software.

\section{Results and Discussion}

\section{Policy Basis for the Recruitment and Promotion of Bureaucratic Officials}

In order to recruit an ideal official, the bureaucracy must refer to what Weber, who aspired for an ideal bureaucracy, mentioned as cited by Warwick (1975:4) who stated that an ideal bureaucracy should among others maintain the following: (1). Rules/regulations and formal standards regulating organizational functions the member behaviors; (2). Personnel who technically meet requirements, are employed based on career, with appearance and qualification-based promotion.

Bearing in mind that recruitment system is based on various legal bases that apply as measurable parameters, recruitment qualifications in regional governments should consequently include requirements determined based on the generally applicable legal umbrella. The legal umbrella is the form of laws and governmental regulations referred to as legal bases in the recruitment and promotion of SCTR bureaucratic officials. Additionally, other provisions also apply, namely Regional Regulations implicitly attached to the establishment of regional organizations (Organisasi Perangkat Daerah - OPD). The legal bases and regulations covering matters relating to recruitment and promotion of Civil Servant 
Appointment in Office are:

1. Law 5/2014 on State Civil Apparatus;

2. Law 23/2014 on Regional Government;

3. Government Regulation 18/2016 on Regional Apparatus;

4. Government Regulation 11/2017 on Management of Civil Servants;

5. Regulation of the Minister of Administrative and Bureaucratic Reform (MENPANRB) of the Republic of Indonesia 15/2019 on Procedures for Filling Senior Executive Service Positions Openly in Government Organizations;

6. Regional Regulation of South Central Timor Regency No. $05 / 2016$ on the Formation and Arrangement of South Central Timor Regency Regional Apparatus;

7. Regional Regulation of South Central Timor Regency No. 18/2007 on Administrative Matters under the Authority of South Central Timor Regency.
The Merit System's Adaptation to the Implementation of Bureaucratic Officials Recruitment and Promotion Policy

A significant challenge faced by the SCT regional government in terms of bureaucratic official recruitment and promotion policy is the inequality of human resource (HR) capacity among bureaucratic personnel. The local community's strong ecological characteristic with diverse social, cultural, geographical, economic, and educational environments, coupled with the salience of kinship and affiliation have set the backdrop for differences in the capacity and performance of bureaucratic HR. Consequently, such conditions have made it difficult for the regional bureaucracy to avoid emergence of $\mathrm{HR}$ capacity disparity issue among bureaucrats.

The HR capacity issue among bureaucratic personnel in the region subsequently intensifies when the initial recruitment tends to be closed, is not based on job analysis, and only conducted

Figure 1.

Visualization of Normative Hierarchical Bases for the Recruitment and Promotion of Officials in SCTR

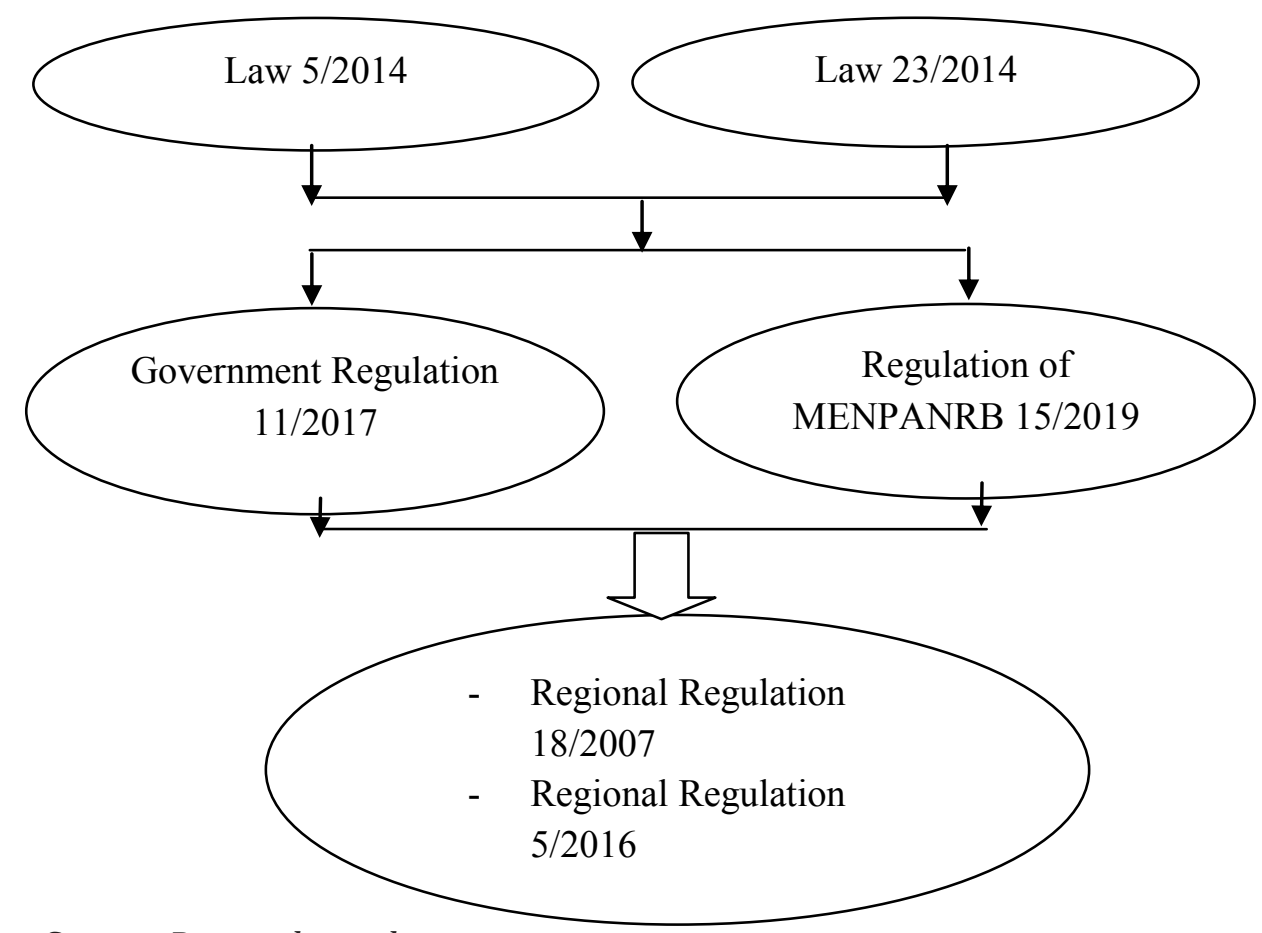

Source: Research results 
to accommodate the political rulers' interests. Recruitments remain considered as though they are a necessary annual activity instead of a need to enhance the quality of public services and administration. This is a very real indication due to the absence of job analysis as a precondition to determine job requirement. Naqib in Herman (2006) states that the dominant factor causing ineffective and non-optimal civil servant performance in providing public services, which may even seem similar to concealed unemployment, is that employee recruitment policies in government organizations are not based on labor planning but on power factors and political interests instead (Herman, 2006). This condition is exacerbated by collusion, corruption, and nepotism without due considerations to individual competence and expertise. The regional culture's strong ecological characteristics coupled with the salience of kinship and affiliations have also resulted in the recruitment process being incapable of producing State Civil Apparatus (Aparatur Sipil Negara - ASN) meeting the qualification requirements. There is even a greater tendency to prioritize native sons in ASN recruitment (Green, 2005).

To address HR inequality among bureaucrats so they can fulfil regulatory demands, SCTR's leaders have currently taken measures to reconstruct the bureaucratic official recruitment and promotion model. The reconstruction is achieved by having the merit system adapt to their bureaucratic official recruitment and promotion policy, which aligns with local contexts and availability of regional bureaucratic HR so that public services can be provided optimally. The recruitment mechanism used in the merit system's adaptation is even developed not only to employ a structural approach model as formal requirements do, but also to employ a cultural approach model without disregarding the minimum requirements demanded in the applicable regulations.

\section{Structural Approach.}

Structural approach means that implementation of bureaucratic position recruitment and promotion aligns with the ideal concept of system and mechanism that normatively apply. This implies that civil servant's career development within the recruitment mechanism in SCTR is to be performed based on qualifications, competence, and needs of the government organization. The most crucial aspects of said career development are integrity and morality. Competence is an absolute condition for civil servants about to hold bureaucratic positions. Competence can be defined as an individual's ability to show his/her work results according to required standards.

Law 5/2014 specifies ASN competence covering: (1). Technical competence measured by education level and specialization, functional technical training, and technical work experience; (2). Managerial competence measured by level of education, management or structural training, and leadership experience; and (3). Sociocultural competence measured by professional experiences relating to plural communities in issues of religion, ethnicity, and culture that lead to having a perceptive insight on nationalism.

Based on analyses of interviews with our informants, it is known that competence-based recruitment and promotion of bureaucratic officials are significant conditions that must be met to enhance public service quality. Aside from being competence-based, local value considerations are also substantial for recruiting and promoting bureaucratic officials. This is quite obvious from the statement the Regent made:
"If we want to advance, competence is vital. ASN must have an education, if necessary up to doctorate level. That's why for the last few years, we have been conducting open bidding for Echelon II positions. While for Echelon III, we also employ internal 


\section{Figure 2.}

Nodes and Sub-Nodes of Promotion and Recruitment Adaptation Mechanism

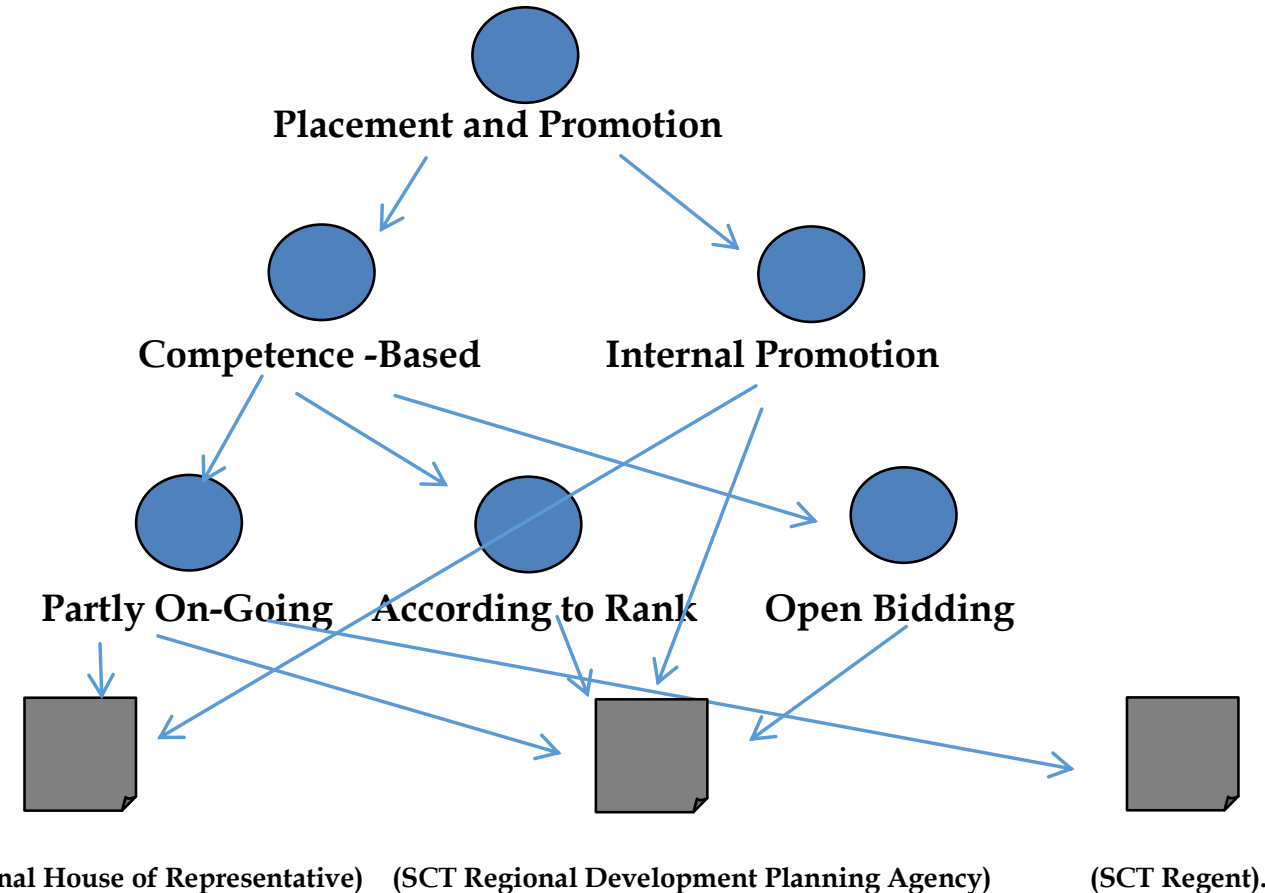

(SCT Regional House of Representative) (SCT Regional Development Planning Agency)

Source: Data Processing Results

considerations in job promotions. Our principle is that competent and professional HR are important. But we also can't neglect local values in the region." (Ir. E.P. Tahun, S.T., M.M.; Regent of SCT 2019-2024 period).

By using NVIVO, data processing results indicate that, in the structural approach, two different mechanisms are employed in the recruitment and promotion of bureaucratic officials in SCTR, i.e. merit-system-based mechanism and internal-consideration-based mechanism. The merit-system-based mechanism is used for recruitment of First Level Senior Executive Service (JPTP) positions. In this mechanism, qualifications, competence, integrity, morality, and compliance to other administrative requirements serve as parameter of considerations in deciding whether someone is acceptable to hold a position in the bureaucracy. The recruitment is done publicly through open bidding. Meanwhile, the later mechanism is conducted by means of internal considerations. It is used for Office Administrator positions. In this particular mechanism, qualifications, competence, integrity, morality, and compliance to other administrative requirements remain considered as points of reference, however, the final decision takes into account a balance based on representativeness and local democracy such as representation of ethnicities, native sons, religious elements, and other local value considerations.

When we compare the practice of recruiting and promoting officials in the context of the structural approach above with the recruitment concept proposed by Almond \& Coleman (1996). Almond (1996) to use as an analytical tool in the study, it is undeniably counterproductive. Almond \& Coleman (1996) only recognized two recruitment models, first is the ascriptive style wherein individuals are chosen to hold a certain position based on bloodline and social status, gender, race, ethnicity, and religious affiliation; and the second model is achievement- 
oriented recruitment, which emphasizes technical expertise and leadership as elements required for the job, and this model also avoids various forms of collusion in every policy made.

Upon observation of the bureaucratic official recruitment and promotion practice in SCTR, it is apparent that the policy model used is a combination of the ascriptive style and achievement-oriented recruitment. In the combined model, representativeness of ethnicity, native sons, religious element, and other local value considerations are taken into account and accommodated in the recruitment mechanism, yet parameters concerning qualifications, competence, integrity, morality, and compliance to other administrative requirements are still considered to determine whether a candidate is acceptable to a hold a bureaucratic position. This combination is subsequently seen as a form of adaptation by the merit system to the strong ecological characteristics of the local community with its diverse and varying social, cultural, geographic, economic, and educational environments, coupled with the salience of kinship and affiliations, and the inequality of HR capacity among bureaucrats.

An interesting point about the combined qualification requirement of the recruitment and promotion model in SCTR in relation to the their perspective on bureaucratic HR availability is that the indicator of competence and best person for the job are not only scrutinized using a merit system parameter in the context of ideal bureaucracy, but they must also be complemented with elaborations regarding constellations, contexts, and local ecological conditions of SCTR with its unwaveringly strong local values.

Competence and best person for the job in the merit system's adaptation are consequently translated into the assertion that determining the best person to hold a bureaucratic position, aside from having sufficient skills and educational background, she/he should also be able to bring the organization, duties, and functions closer with ecological needs, be concerned about the conditions of the region they lead, be able to realize ideas in developing and empowering the community, be able to resolve local issues such as boundary/territorial disputes or interethnic conflicts without being coopted by political interests.

Among the regional government's efforts to enhance the limited HR quality of bureaucrats, so they can fulfil administrative requirements and obtain bureaucratic positions, is by sending potential bureaucrats to take a study leave to pursue higher education level. Additionally, bureaucratic personnel are also given the opportunity to participate in Leadership Training and Education programs and other Technical Education/Training programs in the bureaucracy.

The table below provides an illustration of the bureaucracy's human resource composition in the senior executive service based on education level, as follows:

Table 1.

Education Level of First Level Senior Executive Service (JPTP)/Echelon II.

\begin{tabular}{clc}
\hline No. & \multicolumn{1}{c}{ Education Level } & Total \\
\hline 1. & Doctoral Degree (S3) & - \\
2. & Master's Degree (S2) & 20 \\
3. & Bachelor's Degree (S1) & 19 \\
& TOTAL & $\mathbf{3 9}$ \\
\hline
\end{tabular}

Source: BKPSDMD TTS 2018/2019

Table 2.

Education Level of Office Administrator Position (Echelon III.a)

\begin{tabular}{clc}
\hline No. & \multicolumn{1}{c}{ Education Level } & Total \\
\hline 1. & Master's Degree (S2) & 11 \\
2. & Bachelor's Degree (S1) & 58 \\
3. & Diploma & 3 \\
& TOTAL & $\mathbf{7 2}$ \\
\hline
\end{tabular}

Source: BKPSDMD TTS 2018/2019

\section{Cultural Approach}

The cultural approach in the bureaucratic official recruitment and promotion mechanism is used to observe how the merit system adapts 
to the strong ecological characteristics of SCTR's local community with its diverse and varying social, cultural, geographic, economic, and educational environments. Although the policy is counterproductive to the ideal recruitment criteria, theoretically speaking, the above phenomenon can be analyzed using the representative bureaucracy model. This is similar to the perspective aspired by Lee (via Zauhar, 2007:48-51) who specified bureaucratic typologies based on various perspectives relating to degrees of openness, namely: bureaucracies as observed from the public's accessibility to interact with them; the scope of bureaucratic administration; the freedom of other groups to enter the ranks of high and mid level positions; and the degree that the bureaucracy is willing to distribute its power to others and its relative flexibility.

The merit system's adaptation in the context of representative bureaucracy reflects the conditions and composition of the community in terms of ethnicity, religion, gender, etc. Kernaghan's recruitment model (as quoted in Kim \& Kim, 1999;235) draws attention to the requisite that public service should be a micro cosmos of the entire community. Accordingly, representative bureaucracy is a miniature depiction of the whole community which can lead to administrative responsibility strengthened by the government officials' responsive attitude to the public. Officials are believed to possess social backgrounds that can affect the policies they make and implement, and they ultimately produce policies aspired by social groups present among the populace including local communities.

A study by Sayrani (2017) about the representation dynamics within the government bureaucracy in East Nusa Tenggara Province shows that subsequent manifestation of social plurality within East Nusa Tenggara bureaucracy had led to indications of rivalry and domination among various (ethnic, religious, and gender- based) groups. At the institutional level, there was inclination toward the emergence of unequal access and domination of bureaucratic structural positions among the various groups.

At the political level/field, plurality was managed institutionally through the mechanism of general election which was consequently articulated in the composition of political powers, particularly in the house of representatives (DPRD). However, at the bureaucratic level/ field, the response to plurality did not seem to be properly articulated. Normatively speaking, the bureaucracy tended to respond to plurality in a neutral manner within the frame of the merit-system-based bureaucratic management (meritocracy regime). Nevertheless, on a practical level, contestations and even balancing efforts among the social (ethnic and religious) groups are informally apparent in the bureaucracy.

Unlike Sayrani's, the current study focuses more on how is the merit system's adaptation developed in the practice of recruiting and promoting bureaucratic officials in the region since the structural approach used in the bureaucratic meritocracy mechanism is unable to address existing problems such as the strong ecological characteristics of the local community with its diverse and varying social, cultural, geographic, economic, and educational environments, and salience of kinship and affiliations, coupled with the disparity of HR capacity among bureaucrats in the study location.

By employing Kernaghan (1991) and Warner's (2001) concept of representative bureaucracy as an analytical tool to study the phenomenon of merit system's adaptation in cultural approach, we found that representative practices in SCTR's bureaucracy are more dominantly determined by sociological and political interests. Sociological and political interests here mean that bureaucratic representativeness tends to foster balance and democratic zeal by providing local community 
representatives access to power. Additionally, such accommodative measure is conducted with the expectation that the democratic process in pluralist or multiethnic regions can be well managed using the representative bureaucracy approach.

Data analysis results indicate that the development of merit system's adaptation to the bureaucratic office recruitment and promotion mechanism in SCTR also prioritizes native sons and pays attention to balance of ethnic configuration.

\section{Prioritizing Native Sons}

With the stability of development activities, politics, and security in mind, considering Native Sons in the bureaucratic office recruitment and promotion policy is a crucial factor in SCTR. The parameter of "the right people in the right place" formula applies to people who understand and master their tasks and responsibilities, who have integrity and good moral character, who can be a role model for people they lead, who have the personality to serve even the lowest and most remote constituents, and who is willing to continue to learn and hone their ability. Such typology is what they consider as Native Sons.

Native sons are considered to have a better understanding of the people's social conditions as they are originally from one of these community groups themselves. Another reason to consider is that the public shows greater respect when the government involves more native sons to be appointed as leaders in their respective regions. It is easier for the public to accept and support them as their leaders.

"The competence we want is that certain strategic positions should be given not only to people who have good managerial and intellectual abilities,

Figure 3.

\section{Bureaucratic official recruitment and promotion mechanism}
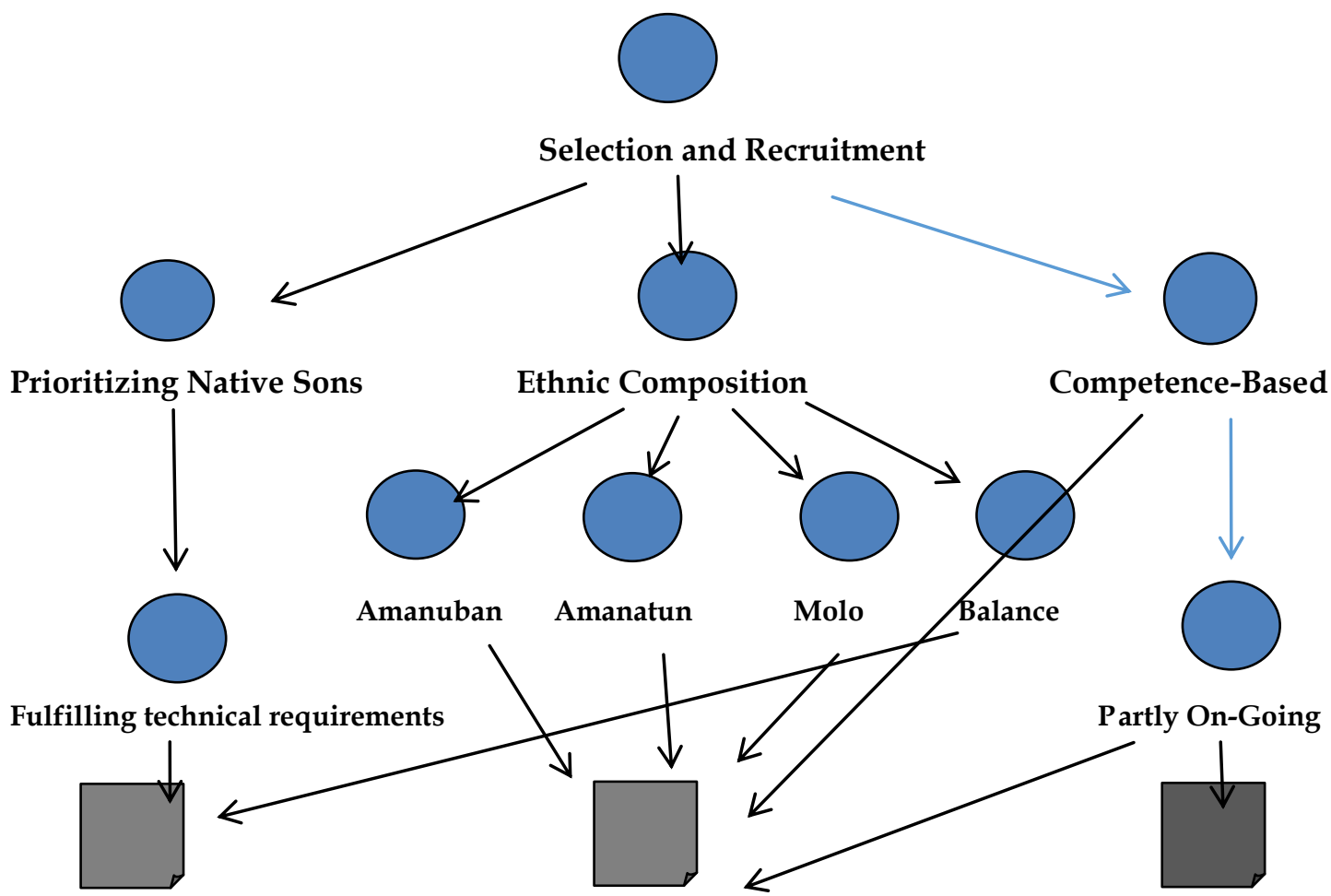

(SCT Regent)

(SCT Regional House of Representative)

(SCT RegionalDevelopment Planning Agency)

Source: Data Processing 
but also to native sons and daughters who are charismatic, revered as a figure, listened to when speaking. These are the individuals that should be appointed to strategic positions for the stability of regional security" (Jean E.M. Neonufa, S.E., Chair of SCTR Regional House of Representatives 2014-2019 period)

The native son consideration is commonly used in the recruitment and promotion policy for Administrator Office level, namely the District Head (Camat) position. In this context, the camat position is considered vital as they are the spearhead of the regional government in realizing the elected regional head's vision and mission for constituents residing in their respective areas, and they must also be able to resolve problems in their district such as territorial disputes, interethnic conflicts, and other local issues.

\section{Paying Attention to Balance of Ethic Configuration}

In the public administration perspective, ethnicity is inherent in every culture of the society, and it is one of the elements of civilized society. Accordingly, ethnicity can be managed in accordance with the development of public administration paradigm through public policies in a multiethnic government. Public administration considers recruitment as a part of management, and management is the essence of administration. Whereas leadership is the essence of management (Siagian, 1985). This means that recruitment and promotion of bureaucratic officials constantly come into contact with the public administration dimension aimed at creating a conducive government system that is integrated in a plural society.

Rasyid (1991) states that recruitment of officials with ethnic background is not taboo to discuss since the phenomenon also happens in Belgium, a highly developed country with a modern government system. There is a kind of consensus to distribute some positions in certain ministries as fixed positions for certain ethnic groups. However, Belgium's distribution is based on linguistic differences. A similar case is observed in Australia. La Ode Ida (2000) asserts one of government bureaucracy's function is to unite different ethnic groups into a single government structure considered capable of fairly representing all parties.

In the context of this research, an agreement leading to a consensus on ethnicity during the early establishment of the SCT autonomous region is indicative of a regional government existing amidst a multiethnic society, hence prompting its government to take strategic measures of having the merit system adapt to the mechanism for recruiting and promoting officials by representing ethnicity in the regional government's public policy.

'In terms of recruiting bureaucratic officials, we really pay attention to the balance of three major ethnicities in the regency: Mollo, Amanatun, and Amanuban. We have a philosophy "Tmeup Tabua Nekaf Mese Ansaof Mese" which means "Work Together, One Heart-One Mind", and this philosophy is an ancestral heritage that we have to maintain and preserve. We accommodate ethnic representation, but we do not disregard technical issues like education, competence of every candidate" (Regent of SCT 2019-2024 period).

The regional government considers ethnic representation as an important factor when holding a bureaucratic position to maintain a permanent balance between power and interests of the multiethnic society. Additionally, the regional government gains legitimate support from the local communities for the power they wield.

Warner (2001) states that balanced representation needs to be developed in public bureaucracy as a manifestation of the spirit of democratic wisdom within an authority. Representation here means ethnic representation 
in the bureaucratic structure as a result of consensus among ethnic groups in the populace during the formation of an autonomous government.

\section{Conclusion}

To date, the practices of our bureaucratic system, despite being made more autonomous, still retain a strong tendency toward a rigid centralistic orientation adhering to the Weberian model, with the formula of the state and/or central government. Observations indicate that a distantly controlled bureaucracy merely generate uniformities often incompatible with each region's varying conditions and situations. Differences in cultural, geographic, and economic conditions generate distinctive needs demanding bureaucratic personnel as dynamic and responsive public servants to quickly adapt in line with conditions required by local community.

Concerning the policy for recruiting and promoting bureaucratic officials in regions with strong ecological characteristics: varying social, cultural, geographical, and educational environments, as observed in SCTR, the merit system's adaptation model needs to be considered within the local context. Our bureaucratic administration system should adapt and respond to its own regional characteristics in accordance with local context. Hence, bureaucratic uniqueness aligned with the region's local character within the frame of the unitary state of the Republic of Indonesia can be achieved. We should learn from Japan, Korea, and China, which to a certain extent have succeeded in leading the world with their respective local characteristics.

The merit system adaptation policy developed in the mechanism for recruiting and promoting bureaucratic officials in the region has its strong and weak points. Its strong point concerns social equity. The merit system's adaptation can accommodate local values as a basis in forming the bureaucracy to avoid inequality and discrimination against bureaucratic personnel who are promoted in the bureaucratic structure.

Another implication is that the merit system's adaptation to the mechanism for recruiting and promoting bureaucratic officials in the region can maintain economic and political stability and security because it can develop balance and democratic zeal by providing local community representatives access to power. Additionally, such accommodative measure is expected so that the democratic process in pluralistic or multiethnic regions can be managed using the representativeness perspective. This means that ecological values of local communities are considered and accommodated without disregarding professionalism as required by regulations that generally apply.

The merit system adaptation policy's weakness is that the bureaucratic personnel's competitiveness becomes lower since no competitor can be set as a benchmark in terms of competence, skill, and professionalism in certain fields of duty. Consequently, the productivity and performance of HR among local bureaucrats become stagnant and even ineffective and inefficient in providing public services.

\section{References}

Almond, G., \& Coleman, J.S. (1996). The Politics of Developing Areas. New Jersey : Princeton University Press.

Bellows, T.J. (2009). Meritocracy and the Singapore Political System. Asian Journal of Political Science. 17 (1), 24-44.

Bernadin, John \& Jpyce E.A Russel. (1993). Human Resource Management. Singapore: Mc, Graw-Hill, Inc.

Castilla, E. J., \& Benard, S. (2010). The Paradox of Meritocracy in Organizations. Administrative Science Quarterly. 55 (4), 543-676.

Collins, R. (1986). Weberian Sociological Theory, Cambridge, MA: Cambridge University Press. 
Czudnowski, M.M. (1975). Comparing Political Behavior. Chicago : Aldine Atherton.

Gordon, G. J. (1982). Public Administration in America. New York, NY: St. Martin Press

Government Regulation 11/2017 on Civil Servant Management.

Green, Amanda. (2005). East Asia Decentralizes. Making Local Government Work. Washington DC : World Bank.

Hale, S.M. (1995). Controversies in Sociology : A Canadian Introduction. Mississauga, Canada : Copp Clark.

Handerson, K., \& Dwivedi, O. (1999). Bureaucracy and the Alternatives in World Perspective (1st ed.). International Political Economy Series.

Henry, Nicholas. (1995). Administrasi Negara dan Masalah-Masalah Publik. Jakarta: PT Raja Graffindo Perkasa.

Herman. (2006). Analisis Implementasi Kebijakan Rekrutmen PNS Nasional. Jakarta: Puslitbang Badan Kepegawain Negara.

Herman. (2012). Meritokrasi Dalam Pengisian Jabatan Pegawai Negeri Sipil di Indonesia. (Doctoral Dissertation Universitas Indonesia, 2012). Depok, Indonesia : Universitas Indonesia.

Imbroscio, D. (2016). Urban Policy as Meritocracy: A Critique. Journal of Urban Affairs. 38 (1), 79-104.

Irawan, B. (2017).Social Equity Dalam Perkembangan Paradigma Administrasi Publik.

Jost, J.T., \& Hunyady, O. (2005). Atecedents and Consenquences of System Justifying Ideologies. Current Directions in Psychological Science, 14, 260-265.

Jost, J.T., Ledgerwood, Alison \& dan Hardin, Curtis D. (2008). Shared Reality, System Justification, and the Relational Basis of Ideological Beliefs. Social and Personality Psychology Compass, 10, 171-186.

Jost, J.T., Pelham, B.W., \& Carvallo, M. (2002). Non Conscious Forms of System Justification: Cognitive, Affective, and Behavioral
Preferences for Higher Ststus Groups. Journal of Experimental Social Psychology, 38, 586-602.

Kernaghan, Kenneth. (1991). A Special Calling : Values, Ethics and Professional Public Service. Canada Public Service Agency. Brock University.

Kim, Suk Pan. (1996). A Theoretical Overview of Representative Bureaucracy. Synthesis. International Review of Administrative Science.

Kim, Wong Bunand Pan Suk Kim. (1999). Korean Public Administration. Hollym : Managing Uneven Development.

Kingsley, J.D. (2003). Representative Bureaucracy. Julie A. D., \& David H. Rosenloom (Ed.). New York, NY :M.E. Sharpe Armonk.

Kumorotomo, Wahyudi. (2006). Demokrasi vs Meritokrasi: Mencari Jalan Tengah dari Kasus Pengangkatan Pegawai Honorer. Makalah tentang Manajemen Pejabat Politik dan Pegawai Birokrasi.

La Ode, Ida. (2000). Otonomi Daerah dalam Interaksi Kritis Stakeholders. Jakarta: Pusat Studi Pengembangan Kawasan (PSPK).

La Palombara, J. (1967). Bureaucracy and Political Development. New Jersey : Princenton Univeristy Press.

Masdar, S. (2008). Pasca 1998, Muncul Intervensi Politisi Terhadap Promosi dan Depromosi Jabatan Struktural. Disertasi Ilmu Administrasi Negara Sekolah Pascasarjana Universitas Gadjah Mada Yogyakarta.

Mas'oed, Mochtar \& MacAndrews, Colin (Eds). (1991). Perbandingan Sistem Politik. Yogyakarta : Gajah Mada University Press.

McClosky, H., \& Zaller, John. (1984). The American Ethos : Public Attitudes Toward Capitalism and Democracy. Cambridge : Harvard University Press.

McCourt, W. (2007). The Merit System and Integrity in The Public Service. IDPM, University of Manchester. 
McKenna, E., \& Nick Beech. (1996). The Essence of Human Resource Management. (Totok, Trans.). Jakarta: Ghalia Indonesia.

Poocharoen, 0., \& Brillantes, A. (2013). Meritocracy in Asia Pacifik : Status, Issues, and Challenges. Review of Public Personnel Administration. 33 (2), 140-163.

Rasyid, R. (1991). Kajian Awal Birokrasi Pemerintahan dan Politik Orde Baru, Jakarta : Yarsif Watampone.

Regional Regulation of SCT Regency 05/2016 on the Formation and Arrangement of SCT Regency Regional Apparatus.

Regulation of the Minister of Administrative and Bureaucratic Reform of the Republic of Indonesia 15/2019 on Procedures for Filling Senior Executive Service Positions Openly in Government Organizations.

Riggs, Fred. W. (1996). Administrasi Negara -Negara Berkembang. Teori Masyarakat Prismatik. Jakarta : CV. Rajawali.

Rush, M., \& Alttoff, Phillip. (2003). Pengantar Sosiologi Politik. Jakarta : Rajawali Press.

Saputra, B., Suripto, S., \& Crisidana, Y. (2018). Indigeneous Public Administration : Melihat Administrasi Publik Dari Perspektif Kearifan Lokal (Local Wisdom). Jurnal Ilmu Administrasi, 15(2).

Sayrani, L. P. (2017). Dinamika Representasi Dalam Birokrasi Pemerintahan Di Propinsi Nusa Tenggara Timur. (Doctoral dissertation Universitas Gadjah Mada, 2017). Yogyakarta, Indonesia : Universitas Gadjah Mada.

Siagian, S. P. (1985). Manajemen Sumber Daya Manusia. Jakarta : Bumi Aksara.
Stahl, Glenn. O. (1971). Public Personal Administration. New York, NY: Harper \& Row, Publishers.

The Constitution of the Republic of Indonesia No.5/2014

The Constitution of the Republic of Indonesia No.23/2014

Turner, M., \& Halligan, J. (1999). Bureaucracy and the alternatives in East and Southeast Asia. In Henderson, K.M., \& Dwivedi, O.P (Eds.), Bureaucracy and the Alternatives in Word Perspective. Basingstoke : Macmillan.

Van Riper. (1971). History of the United States Civil Service. Evanston, II : Row and Peterson.

Warner, B.W. (2001). John Stuart Mill's Theory of Bureaucracy Within Representative Government Balancing Competence and Participation. Washington : Public Administration Review.

Warwick, Donald P. (1975). The Theory of Public Bureaucracy. Cambridge, MA: Harvard University Press.

Weber, Max. (1904 [1958]). The Protestant Ethic ad Th Spirit of Capitalism. New York: Charles Scribners.

Wiederkehr, V., Bonnot, V., Krauth-Gruber, S., \& Darnon, C. (2015, July). Belief in School Meritocracy as a System-Justifying Tool for Low Status Students. Frontiers in Psychology, 6,1053.

Wungu, J. \& Brotoharsojo, H. (2003). Merit System. Jakarta : PT. Raja Grafindo Persada.

Zauhar, S. (2007). Reformasi Administrasi. Jakarta: Bumi Aksara. 